\title{
ECONOMICS
}

\section{PRE-INDUSTRIAL BIMETALLISM: THE INDEX COIN HYPOTHESIS}

\section{by}

Ernst Juerg Weber Business School The University of Western Australia 


\title{
Pre-industrial Bimetallism: The Index Coin Hypothesis
}

\author{
by \\ Ernst Juerg Weber* \\ University of Western Australia \\ Business School - Economics Program
}

\begin{abstract}
$\underline{\text { Abstract }}$
In early monetary systems the unit of account was separate from the medium of exchange. Commodity prices and prices of coins were quoted in terms of a fixed quantity of metal that was embodied by an 'index coin'. Coins circulated at their metal value because coinage was imperfect and fixed exchange rates would have interfered with the operation of bimetallism. An indication that the exchange rates of coins were market determined is the absence of value marks on coins. During the Industrial Revolution, improvements in the quality of coinage led to the fusion of the unit of account and medium of exchange function of money. As a consequence, pre-industrial bimetallism gave way to nineteenth century bimetallism, in which the make of currencies alternated between silver and gold.
\end{abstract}

\footnotetext{
* An earlier version of this paper benefited from comments by participants in seminars held at the University of British Columbia, University of California (Santa Cruz), University of Chicago, University of Georgia, University of Rochester, Rutgers University, University of Toronto and University of Western Australia in 2000. I would also like to thank John Melville-Jones for helpful comments. All errors and omissions remain the responsibility of the author.
} 
Bimetallism prevailed for almost two and a half millennia, from the origins of coinage in antiquity until the nineteenth century. In early bimetallism full-valued gold coins circulated side by side with silver coins, occasionally supplemented by token coins, which were made of an alloy of base metals. During the Industrial Revolution, the historic bimetallic standard degenerated, giving way to a bimodal monetary standard, in which, depending on market conditions, the make of currencies alternated between silver and gold. Unlike pre-industrial bimetallism, nineteenth century bimetallism was essentially monometallic, with each metal intermittently serving as medium of exchange. By the end of the nineteenth century, all major countries were on monometallic standards: Europe and America on gold and Asian countries on silver. Compared with the endurance of bimetallism, the gold-standard era was short, providing a mere transition period between historic bimetallism and the modern paper standard that eventually arose during the twentieth century.

Monetary economists tend to deplore the demise of bimetallism. ${ }^{2}$ Friedman (1990a,b) argues that the abandonment of bimetallism by the United States was a costly policy mistake that went largely unnoticed when Congress debated the Coinage Act of 1873. Gallarotti (1994) suggests that policy makers succumbed to a "growing ideological attraction to gold" in both Europe and the United States. Oppers (1996) takes this as evidence that Germany and the Latin Monetary Union capriciously switched to gold in the 1870s. Flandreau (1996) calls the emergence of the international gold standard a "blatant failure of international cooperation." However, the fact that bimetallism was abandoned universally and permanently makes it unlikely that the adoption of monometallism was an inadvertent policy mistake. It is also unclear why this alleged policy mistake should have occurred in the $1870 \mathrm{~s}$ and not at another time, maybe two hundred years earlier? The main flaw of the view that the switch to monometallism was avoidable is that it compares the gold standard, which took hold in the second half of the nineteenth century, with the degenerate nineteenth century bimetallism that preceded it. De facto monometallism had emerged in most industrial countries already decades before the official change to gold, which simply recognized the

\footnotetext{
${ }^{2}$ The main advantage of nineteenth century bimetallism was that the purchasing power of the monetary unit was more stable than in monometallism, at least as long as both metals remained in circulation. For analyses of nineteenth century bimetallism see Niehans (1978, ch. 8), Barro (1979), McCallum (1989, ch. 13), Redish (1995), Dowd (1996), Eichengreen (1996, ch. 2), Sargent and Smith (1997) and Flandreau (2004).
} 
prevailing state of monetary affairs. Thus, the historic dividing line between bimetallism and monometallism lies not in the 1870s, but decades earlier (in Great Britain more than a century earlier), when pre-industrial bimetallism, in which gold and silver coins circulated side by side, gave way to alternating nineteenth century bimetallism.

This paper reviews the history of bimetallism from antiquity until the nineteenth century. The analysis focuses on the fundamentals of bimetallism, namely the technological and institutional conditions that determined the process of coinage. The main argument is (1) that pre-industrial bimetallism differed from nineteenth century bimetallism and (2) that technical advances in the process of coinage made bimetallism unworkable during the Industrial Revolution. In pre-industrial times the unit of account was separate from the medium of exchange because the quality of coins was poor. The crux of the argument is that there is no obvious unit of account in a metallic monetary system with heterogeneous coinage. As there was no high quality coin that could have served as unit of account, how did merchants quote prices and in what unit of account did they conduct commercial calculations? The hypothesis in this paper is that pre-industrial merchants used the official mint weight of a leading coin of their hometown for accounting purposes. Thus, both commodity prices and prices of coins (exchange rates) were quoted in terms of a fixed quantity of metal, embodied by an 'index coin'. ${ }^{3}$ Even specimens of the index coin had a market price that deviated from parity because of wear and tear and deliberate abuse. Therefore, the index coin did not enjoy a decisive advantage as a medium of exchange, and it circulated side by side with other coins, even though its official metal weight served as unit of account. The index coin stayed on an equal footing with other coins as a medium of exchange until the Industrial Revolution. Then, the quality improvement in coinage gave rise to de facto monometallism by fusing the unit of account function of the index coin with the medium of exchange function. The ability to circulate at par gave the index coin (and its multiples and fractions) a decisive advantage as medium of exchange. At the same time, the operation of Gresham's Law frustrated attempts to retain a bimetallic coinage by defining the unit of account in both silver and gold. Thus, the quality improvement in coinage lies at the

\footnotetext{
${ }^{3}$ In Weber (1996) I used the term 'link coin', following a practice found among economic historians (see Lane and Mueller (1985) and Harl (1996)). I now prefer the term 'index coin' because its official mint weight anchors the price level.
} 
root of the transformation of pre-industrial bimetallism to de facto monometallism during the nineteenth century. ${ }^{4}$

The index coin hypothesis complements standard price theory in order to explain the purchasing power of money in a monetary system with heterogeneous coinage. Economic forces determine the exchange value of a unit of monetary metal and the official mint weight of the index coin anchors the purchasing power of the unit of account. The mint weight of the index coin, the inverse of the official price of the monetary metal, is a purely nominal concept, playing the same role as the money stock in a paper standard. Deliberate changes in the mint weight of the index coin produced proportional changes in the purchasing power of the unit of account. This paper applies the index coin hypothesis to the monetary systems of ancient Greece (Section 1), Rome (Section 2) and the Middle Ages (Section 3), and to the transition of pre-industrial bimetallism to de facto monometallism during the Industrial Revolution (Sections 4 and 5). The conclusion (Section 6) relates the index coin hypothesis to issues in modern monetary economics.

\section{The Origins of Bimetallism in the Greek World}

Coinage was invented in western Turkey in the late seventh century BC. ${ }^{5}$ The region was inhabited by Greeks, who lived in coastal cities, and by the Lydians, whose capital Sardes lay further inland. The earliest coins consisted of electrum, a natural alloy of gold and silver (white gold), which was found locally in alluvial deposits. Geological processes determined the composition of natural electrum, although mints quickly mastered the technique of alloying electrum. The analysis of two coins yielded $47.8 \%$ and $50.0 \%$ of gold, and $47.0 \%$ and $43.3 \%$ of silver, the remainder being accounted for by impurities (Cooper 1988 , p. 8). Electrum coins played a significant role in early monetary history, circulating in western Turkey and the Black Sea area from the seventh until the fourth centuries BC.

\footnotetext{
${ }^{4}$ Redish (1990, 2000) and Sargent and Velde (2002) pointed out the importance of changes in minting technology for the operation of metallic monetary standards. Their analysis focuses on the role of token coins in the gold standard. Selgin (2003) questions their finding that the mechanization of mints solved the small-change problem.
}

${ }^{5}$ Sources for this section include Melville-Jones (1986), and Carradice and Price (1988). 
Remarkably, the history of coinage had started with a symmetallic standard, as envisaged by Marshall (1887). ${ }^{6}$

The legendary Croesus (561-546 BC), the last king of Lydia, is often credited with the creation of pure silver and gold coins. But silver coins emerged on the island of Aegina, across the Aegean Sea, at about the same time (and possibly somewhat earlier). In the sixth century $\mathrm{BC}$, coinage spread from western Turkey to the Greek mainland and beyond to Greek cities in Sicily and southern Italy. Apart from the early use of electrum, Greek cities almost exclusively struck silver coins until well into the classical period (the time from the Persian wars (492-479 BC) until Alexander the Great (356-323 BC)). The first significant amount of gold coinage was issued by Athens when Sparta occupied the silver mines at Laurium during the Peloponnesian War (431-404 BC). Philip II (382-336 BC), who established Macedonian hegemony in Greece, minted both silver and gold coins, although most gold coins may have been issued posthumously by his son Alexander (Carradice and Price 1988, ch. 7). ${ }^{7}$ On the Persian campaign, Alexander founded a large number of mints, introducing the practice of coinage as far eastward as the Indus valley. Earlier, coins had been struck only in the western satrapies (provinces) of the Persian Empire, in the former kingdom of Lydia.

Almost every Greek city and island minted coins, displaying a variety of designs, including animals, mythological figures and gods. Some coins were more ubiquitous than others (for example the Athenian silver 'owls' in the second half of the fifth century BC), but no mint ever established a monopoly in the Greek world. The 'owls' of Athens competed with the 'turtles' of Aegina, the 'colts' (named after Pegasus) of Corinth, and other coins. At the pinnacle of Hellenistic influence, during the fifth and fourth centuries BC, Greek coins circulated freely in the Mediterranean and the East, from Spain to the Indus valley.

\footnotetext{
${ }^{6}$ Symmetallism differs from nineteenth century bimetallism inasmuch as the monetary unit is defined in terms of a composite consisting of fixed parts of silver and gold (and not independently in terms of both silver and gold). For this reason, there exists no imputed relative price between silver and gold that might differ from the market ratio, the Achilles' heel of nineteenth century bimetallism. Marshall's idea was to choose the relative weights of silver and gold in order to stabilize the price level. Friedman (1951) extended the concept of symmetallism to commodity-reserve currencies.

${ }^{7}$ Early Celtic coinage imitated Philips's silver and gold coinage (Collis 1984, p. 144). Nash (1987) discusses coinage in the Celtic world.
} 
Alexander put his portrait on imperial coins, but his rule was too short to secure a lasting dominance of imperial coinage. After Alexander's death, the diadochi (Alexander's generals) carved up the empire and new royal coinages emerged. During the Hellenistic period, which lasted from Alexander's death until the ascendancy of Rome, Greek coinage became so complex that, according to Carradice and Price (1988, p. 122), "no coherent account of it has ever been produced."

The names of Greek coinages, stater and drachma, are derived from commercial weights. The word stater means "that which balances the scales", and drachma originated from drax, the Greek word for a "handful of spits". As commercial weight standards varied across cities, coinages were struck to mixed standards. The Corinthian stater weighted 8.6 grams, the Aeginetic stater was 12.2 grams, the Milesian or Lydian stater was 14.1 grams, and the Euboeic stater was 17.2 grams. The drachma represented a smaller weight: 2.85 grams at Corinth, somewhat over four grams at Athens, and slightly over six grams at Aegina. Hence, the Corinthian stater was a three-drachmae piece, the Aeginetic stater was a didrachmon, with similar relationships existing elsewhere. Coinages included elaborate sets of multiples and fractions of the basic monetary unit. Multiples usually followed the dual system (didrachm, tetradrachm) and fractions were expressed as one sixth. The obol was one sixth of a drachma.

The legacy of Greek coins suggests that merchants were accustomed to use a heterogeneous coinage that was issued by a large number of mints. In this monetary environment, how did merchants quote prices and in what unit of account did they conduct commercial calculations? The hypothesis in this paper is that the unit of account was separate from the medium of exchange. Accordingly, merchants used the official mint weight of a leading coin of their hometown for accounting purposes. Thus, both commodity prices and prices of coins (exchange rates) were quoted in terms of a fixed quantity of metal, embodied by an index coin. Even specimens of the index coin had a market price that deviated from parity if they were badly worn. If for example the drachma of Athens served as index coin, then all other coins were valued in terms of the official silver weight of the drachma (somewhat more than four grams), while underweight drachma pieces traded at a discount. For this reason, the drachma did not enjoy a decisive advantage as medium of exchange, and it circulated side by side with other coins, even though its official silver weight served as unit of account. 
The omission of value marks on Greek coins suggests that they circulated at market determined exchange rates. Value marks would have been a nuisance because they would have conflicted with actual exchange rates if coins were imperfect. In monetary history the absence of value marks is a reliable sign that coins traded at exchange rates that depended on their true metal weight and prevailing metal prices. Major coins lacked value marks from antiquity until the eighteenth century (with a notable exception during the late Roman Republic). On the other hand, the use of value marks indicates that coins were designed to circulate as tokens whose assigned values exceeded their true metal value. In Greek times, tokens were used only for emergency issues and minor denominations. Among the earliest tokens were those of Timotheus, an Athenian general, who paid his troops with bronze coins in the war against the Chalcidian League (364-359 BC). The coins, which were marked with one or two dots, were designed to pass for one or two obols. It remains an open question whether Timotheus's promise to redeem the coins after the war and his prospects of victory were sufficiently credible to establish parity with the silver obol. ${ }^{8}$

In general, the quality of Greek coins was high, although there are examples of carefully filed coins, in particular from the early centuries of coinage. This confirms that coins circulated at market determined exchange rates. Free exchange rates between coins protected against deliberate abuse because it is not worthwhile to painstakingly clip and file coins if this reduces their value by the very amount to be gained through these practices. The abuse of coins is profitable only if maltreated coins can be passed on at official exchange rates, irrespective of their true metal weight. Since the valuation of coins required special skills, some cities, for example Athens in c. 375 BC, employed officials who tested coins and settled disputes among merchants. According to an inscription, the officials certified local coins (and possibly foreign coins that were at par with local ones), giving them legal tender status. ${ }^{9}$ Yet, the certifiers did not impose unrealistic exchange rates because this would have led to the widespread abuse of coins, for which, unlike in medieval Europe, there is no evidence in Greek times. For these reasons, in Athens the index coin was the drachma, which was accepted by tale (by counting individual coins) if it conformed to the official standard,

${ }^{8}$ Dots were also used on early bronze tokens in Greek colonies in Sicily, indicating the number of unciae.

${ }^{9}$ Melville-Jones (1993, p. 59) reprints the inscription. 
and which, together with foreign coins, was traded at market determined rates if it was underweight.

Deliberate inflation through a reduction in the mint weight of the index coin was uncommon during antiquity. Usually, the mint weight of the index coin remained close to the corresponding commercial weight standard. Commercial weights that were inscribed with their coin equivalents show that the mint weight of the Athenian drachma was only about five percent less than the commercial drachma weight (Carradice and Price 1988, p. 92). Actually, this may have been the brassage (mint-charge). In the ancient world currency competition prevented deliberate inflation by a single city because the public could easily switch to more stable coinages, putting the mint of the inflating city out of business. The only substantial monetary debasement occurred in Ptolemaic Egypt, at the periphery of the Hellenistic world. ${ }^{10}$ The distant location of Egypt, which could be reached only by sea and through deserts, enabled the monetary authority to suppress currency substitution by controlling the influx of foreign coinage.

\section{Roman Monetary Standards}

During the first half of the third century BC, Rome gained control of peninsular Italy. ${ }^{11}$ Then, the struggle for supremacy in the western Mediterranean led to three wars with Carthage, the so-called Punic Wars (264-241, 219-202, and 149-146 BC). After civil wars in the first century BC, the Roman Republic gave way to the Imperial system, which survived until the fifth century AD. Rome operated several monetary systems during its long history: key dates include the currency reform during the Second Punic War and the introduction of imperial coinage. Accordingly, it is convenient to distinguish between three time periods in Roman monetary history: the early Republican monetary system before the Second Punic War, the Republican monetary system from the Second Punic War until the end of the Republic, and the Imperial monetary system.

\footnotetext{
${ }^{10}$ Heichelheim (1930) analyzes the Ptolemaic monetary system, drawing on the large number of papyri that have survived from this period.

${ }^{11}$ Sources for this section include Crawford (1974, 1985), Burnett (1987), Melville-Jones (1990) and Harl (1996).
} 


\section{Early Republican Money}

At the beginning of the third century $\mathrm{BC}$, Rome had a primitive bronze coinage. As the value of bronze was low, early Roman bronze 'coins' consisted of unwieldy bars and discs that were ill-suited for commercial transactions. The bronze bars, which were adorned by various designs, weighed about 1.5 to 1.6 kilograms, and the largest disc, the 'as', was initially one Roman pound (about 324 grams). ${ }^{12}$ Bronze bars and coins were manufactured through casting, which is less precise than striking coins. Despite the shortcomings of bronze coinage, Rome produced only small quantities of silver drachmae and virtually no gold coins before the Second Punic War. Instead, Romans used silver drachmae from Hellenistic cities in southern Italy, whose monetary systems were more advanced.

The early Roman monetary system operated along the principles of a metallic monetary standard with heterogeneous coinage. Roman merchants had to deal with an uneven domestic coinage and a variety of foreign coins. The leading local coin, the bronze 'as', served as index coin, providing the unit of account in the early Roman system of reckoning. The 'as' system of account defined a wide range of denominations, whose coherence appears to have been a Roman innovation. A dupondius was worth two asses, while the subdivisions of the 'as' included the semis (1/2), triens (1/3), quadrans (1/4), sextans (1/6), uncia (1/12) and semuncia (1/24). These denominations were applied to both money of account and money in coin. ${ }^{13}$ Small coins carried value marks in the form of pellets that stood for one uncia. The use of value marks suggests that the subdivisions of the 'as' were accepted by tale because value marks implied fixed exchange rates between coins. Small coins circulated by tale because the transaction costs of assessing small change would have been prohibitive in daily dealings. Even modest commercial transactions, however, required a heavy load of bronze coinage - bars and discs - which were used at true metal weight. Thus, although the official mint weight of the 'as' served as unit of account, 'as'

\footnotetext{
${ }^{12}$ Roman weights included the libra (pound), uncia and scrupulum. One pound equaled 12 ounces and one ounce was 24 scruples. Approximate modern weight equivalents are: pound (324 grams), ounce (27 grams) and scruple (1.125 grams), but Roman weights are uncertain. The scruple is often defined as 1.137 grams, although this is inconsistent with the likely weight of the pound (324 grams).

${ }^{13}$ Other multiples and fractions of the 'as' unit of account included decussis (10), quinquessis (5), quadrussis (4), tressis (3), bes (2/3) and quincunx (5/12). These values were rarely used for coinage.
} 
coinage did not enjoy a decisive advantage as medium of exchange because, along with all other coins, it had to be valued in terms of 'as' money of account in commercial transactions.

Rome abandoned the bronze standard during the Second Punic War. Between 218 and $214 \mathrm{BC}$, the official mint weight of the bronze 'as' fell from ten to three ounces. The usual explanation for this is that fiscal stress during the war destroyed the Roman bronze standard. Accordingly, Rome deliberately debased the 'as' in order to finance the war. However, the military demand for bronze, which was used for armor and weaponry, probably increased the value of bronze. Therefore, the reduction in the mint weight of the 'as' may have been designed to offset the deflationary effect of a rise in the value of bronze. The debasement of the 'as' by $70 \%$ allowed for a tripling of the bronze price, which does not appear unrealistic during a major war. This interpretation suggests that the bronze standard was abandoned because of excessive fluctuations in the value of bronze during the Second Punic War. ${ }^{14}$ Another motive for the introduction of precious metals coinage was that lowvalue bronze coinage was unsuitable to meet the needs of wartime finance. The upkeep of large armies would have required literally shiploads of bronze.

\section{Republican Money}

Around 211 BC, Rome adopted a bimetallic silver-gold standard that quickly turned into a de facto silver standard. The new index coin was the silver denarius, which initially weighed about 4.5 grams or four scruples, with a high degree of fineness (about 98\%). Despite the emphasis on precious metals (in practice silver), the new monetary standard still showed vestiges of the earlier predominance of bronze, as Romans continued to reckon in asses. But counting in asses had become an empty custom because one 'as' in money of account always equaled one tenth of a denarius, the index coin in the new silver standard. The official mint weight of the silver denarius determined the purchasing power of the 'as' in money of account. At the same time, the tangible 'as' became a low quality token coin, whose composition and weight was subject to great variation.

Rome created the first coinage with explicit value marks in monetary history. The 'as' bore the Roman numeral I, making it the unit of account. The silver denarius, the true index

${ }^{14}$ During the Roman Republic, the silver-bronze ratio was volatile, with a normal ratio of 1:120, and (tentative) extremes of 1:60 and 1:625 (Melville-Jones (1986, p. 143) and Heichelheim (1930, p. 28)). 
coin, carried the numeral X, stipulating a value of 10 asses. Gold coins were struck in three denominations: $\downarrow$ X (sixty asses), XXXX (forty asses) and XX (twenty asses). The silver coins below the denarius, the quinarius and sestertius, were marked V and IIs, indicating 5 and 2.5 asses. The 'as' was subdivided into 12 ounces that were represented by pellets on the triens $(\cdots)$, the quadrans $(\cdots)$, the sextans $(\cdot \cdot)$ and the uncia $(\cdot)$. The semis was marked by an $\mathrm{S}$ (in lieu of six pellets), while the smallest coin, the semiuncia, displayed the symbol $\varepsilon .^{15}$

The introduction of value marks profoundly changed the operation of the Roman monetary system because they gave coins legal tender status in transactions that were defined in terms of asses. Mommsen (1860, pp. 194-95), whose work on ancient monetary systems influenced monetary historians and numismatists well into the twentieth century, clearly recognized the legal tender aspect of value marks:

"It was not only to assist in recognition and valuation of pieces that the Romans marked their money. ... There was a law which gave to money so marked an official value, independent of its intrinsic value ... these pieces alone were considered as coins, and all other kinds of money were in the eyes of the law but merchandise. All commercial transactions in national money so prescribed gave rise to a special and very severe procedure (actio pecunice certa), all others gave the right only to the repayment of equivalent value, and could give rise only to a simple action (quanti ea res est). Whoever made a contract by weight doubtless did not lose the right of weighing when it pleased the creditor to pay him in asses, but whoever had to receive a fixed sum in asses had not the right to ask that they should be weighed, and had to accept them whatever their weight and fineness." (Translated by Burns (1927, p. 380, n. 2))

Thus, coins that bore value marks were used by tale in transactions that were defined in the 'as' unit of account.

The application of value marks seriously impaired the working of Republican bimetallism because the assigned values engendered fixed exchange rates between silver and gold coins. As predicted by Gresham's Law, Republican bimetallism almost immediately

${ }^{15}$ At the beginning of the denarius period, Rome issued large quantities of silver victoriatii, which were somewhat lighter and less fine than the denarius. The victoriatus, whose role in the Roman monetary system remains controversial, did not carry a value mark. 
collapsed into a de facto silver standard because silver coins were officially overvalued relative to gold coins. ${ }^{16}$ A sixty 'as' gold piece weighed about 3.35 grams and a silver denarius (equivalent to ten asses) was 4.5 grams (Crawford 1974, p. 154). This implied an official silver-gold ratio of eight, which was far below the normal market ratio that lay between ten and thirteen in antiquity. It is uncertain why the founders of Republican bimetallism chose an official silver-gold ratio that was too low. They may have done so because precious metal prices were distorted at the inception of bimetallism during the Second Punic War. It is suggestive that the influx of war booty - silver and gold - started in $212 \mathrm{BC}$, shortly before the currency reform.

There existed two ways to create deliberate inflation in the Republican 'as' system of account. The monetary authorities could reduce the purchasing power of the 'as' by debasing the silver denarius or they could directly devalue the 'as' in terms of the denarius. The official mint weight of the denarius remained fairly stable during the Republic. The only substantial debasement occurred during the first half of the second century BC, when the mint weight of the denarius fell from 4.5 to 3.9 grams. However, in $141 \mathrm{BC}$ the Roman monetary authorities reduced the value of the 'as' unit of account to 1/16 of a denarius. Accordingly, the value mark on the denarius was changed from X to XVI. This devaluation of the 'as' destroyed its usefulness as unit of account. Indeed, Romans reckoned in 'as' until its devaluation in 141 $\mathrm{BC}$ and in sestertii afterwards. But the devaluation of the 'as' did not affect the pivotal role of the denarius in the Roman monetary system. The denarius remained the index coin because one sestertius equaled one quarter of a denarius as unit of account.

The Roman Republic often turned moneys of former foes into provincial coinages. This pragmatic attitude avoided disrupting commerce and it saved the cost of recoinage, but it made Roman coinage more complex. During most of the Republican era, the denarius circulated in the core provinces in Italy and in the western Mediterranean, where the conflict with Carthage had ended with the total destruction of Carthaginian civilization. In the eastern Mediterranean the Romans, who admired Greek civilization, assimilated local customs. It

${ }^{16}$ The choice of monetary metal may be understood as Nash equilibrium. Merchants set commodity prices (in terms of 'as' money of account) expecting that people would use overvalued silver coins in payments. Vice versa, people used overvalued silver coins because merchants set commodity prices accordingly. Rolnick and Weber (1986) and Sargent and Smith (1997) deal with the microeconomic foundations of Gresham's Law. 
took about a century from the annexation of Macedon (148 BC) and western Turkey (129 BC) until Roman money spread to the East. Still, the economic significance of provincial coinages should not be overemphasized, however interesting they may be from a numismatic standpoint. After the Second Punic War, Rome ran a national monetary system that was based upon the silver denarius. It seems likely that provincial coinages were valued in terms of the prevailing unit of account, first the 'as' and then the sestertius, in commercial transactions.

\section{Imperial Money}

During the civil wars in the first century BC, most protagonists struck coins. Julius Caesar marched on Rome in 49 BC, where he seized the well endowed Republican treasury. This windfall enabled him to strike vast quantities of silver denarii and gold aurei, which undoubtedly strengthened his political position. Despite the civil strife, the quality of Roman coinage remained strong in the first century BC. The military leaders operated in a highly competitive environment with shifting spheres of influence that depended on the tide of war. Intense competition - economic, political and military - prevented them from inflating by reducing the mint weight and fineness of coins. People could easily switch between coinages, making the demand for each brand of coins sensitive to changes in purchasing power. Only Mark Antony struck substandard denarii shortly before his downfall, a desperate measure that did not save him.

Unlike Republican precious metal coinage, Caesar's coinage did not carry value marks. He must have been aware of the fact that Republican bimetallism had failed because silver coins were officially overvalued relative to gold coins. The deliberate omission of value marks gave rise to a bimetallic coinage in which silver and gold coins circulated jointly at market determined exchange rates that were quoted in terms of sestertii. Crawford (1985, p. 243) notes that the denominations of Caesar's gold coins remain uncertain. Caesar's return to unmarked coinage provided a watershed in Western monetary history that has not yet found due recognition among monetary historians. From Caesar's time until the eighteenth century, precious metal coins did not carry value marks. For almost two millennia, major coins were designed to circulate at market determined exchange rates that, taking account of 
wear and tear and deliberate abuse, depended on the true metal weight of coins and metal prices.

In $27 \mathrm{BC}$, Octavian became the first Roman emperor, assuming the name of Augustus. His role in establishing imperial coinage is often exaggerated. By the time he ascended to the imperial throne, a bimetallic monetary system had already emerged. At its heart, Augustan precious metal coinage was Caesarean. Augustus's contribution to imperial coinage was limited to the reform of base coinage, abandoning low quality bronze in favor of brass (sestertius and dupondius) and copper ('as', semis and quadrans). But the make of base coinage was irrelevant because token coins circulated at assigned values in small daily transactions.

One complication arises because one Augustan aureus was officially tariffed at 25 denarii. It seems that this official tariff was a less effective way of fixing exchange rates between coins than the earlier use of value marks. Unlike Republican coinage, imperial coinage remained bimetallic for centuries. In fact, the prevalence of the sestertius unit of account explains why the official tariff between the silver denarius and gold aureus did not impede the working of bimetallism. Suppose a merchant bought commodities with a price of 100 sestertii. Since sales contracts specified prices in sesterii, the merchant could pay by using any type of coin with a market value of 100 sestertii. There existed no opportunity to pay less by using aurei when gold was momentarily cheap. As coins were not denominated in sestertii, the seller was not obliged to accept aurei with a market value of less than 100 sestertii. The official tariff remained ineffective because it is not possible to fix a relative price, here between silver and gold coins, by pure fiat. ${ }^{17}$ The market ratio of aurei in terms of denarii often deviated from the official tariff of 25 . There arose no arbitrage opportunity because no institution traded silver and gold at the official tariff. The emperors were not in the business of providing a grateful populace with an unlimited supply of undervalued coins that could be melted down at a profit. It seems that some recoinages during the first century

\footnotetext{
${ }^{17}$ Suppose the government legislates that one apple should trade for three oranges. This would be of no consequence because, without coercion, no market would emerge in which the two commodities are exchanged at the official ratio. Effective price controls always involve money prices of commodities. Monetary regulations during the Roman Republic (and later during the eighteenth and nineteenth centuries) interfered with bimetallism because, using value marks on coins, the relative price of silver and gold was fixed indirectly by setting the money prices of silver and gold.
} 
were motivated by the desire to realign the market ratio between denarii and aurei with the official tariff of 25 .

From Caesar's time until the early third century, the weight of the silver denarius dropped from about 3.9 to 3 grams, and its fineness was approximately halved to $50 \%$. This amounted to an average debasement of about $2.1 \%$ per year. In the same time period, the gold aureus fell from about 8 to 6.5 grams. The slow deterioration of precious metal coinage was interrupted by several short-lived attempts to restore it. During the fourth century, economic and social conditions worsened in the Roman Empire. The weight of the aureus fluctuated strongly and the denarius became a base coin. In 301, Diocletian ( 243-316) resorted to price controls in order to restrain inflation. Soon afterwards, Constantine ( $280-$ 337) established a gold standard that was based on the solidus.

\section{Medieval Money}

After the demise of the Roman Empire, Europe experienced a period of social and economic retrogression. ${ }^{18}$ By the sixth century, trade had come to a virtual standstill and, as a medium of exchange was no longer needed, the economy became almost completely demonetized. Precious metal coinage was either hoarded or it was spent on luxuries that were imported from northern Africa and the East. During the eighth century, the revival of trade in the region of the English Channel and the North Sea generated a fresh demand for means of payment. A new silver penny coinage emerged, which dominated the European monetary system for the next five centuries. By the eighth century, the late Roman solidus system of account had given way to the medieval $£ / s / d$ system; one pound usually equaled 20 shillings and one shilling was 12 pence. The notation $£ / s / d$ is etymologically linked to the Roman libra (pound), solidus and denarius. From the tenth to the thirteenth centuries, Europe experienced a period of prosperity that coincided with an expansion of silver mining in eastern Europe and an influx of gold across the Sahara from western Africa. In the thirteenth century, at the beginning of the Renaissance, northern Italian city states introduced gold coins that became popular means of payment at fairs and in cities along Europe's trade routes. From then until the Industrial Revolution, European coinage included silver and gold coins.

\footnotetext{
${ }^{18}$ Sources for this section include Spufford (1988) and Weber (1996).
} 
Economic historians are often uncertain about the nature of medieval money. The difficulty is that it is usually not possible to establish a clear-cut relationship between pound money of account and a specific index coin. Knowledge of medieval monetary regulations is incomplete and medieval coins did not carry value marks in terms of $£ / s / d$. As a consequence, many economic historians have been influenced by the idea that the pound was an 'abstract' or 'imaginary' unit of account whose purchasing power did not depend on that of an index coin. In particular, Einaudi $(1937,1953 / 36)$ insisted that the purchasing power of the pound was determined solely by "the common opinion of the people." 19

The notion of abstract money of account does not provide an effective tool for the analysis of the medieval monetary system. The fact that it is now difficult to determine what coin acted as index coin does not mean that there was no index coin at all. In fact, the medieval monetary system strongly resembled that of ancient Greece. Reflecting the political fragmentation of medieval Europe, coins were supplied by a large number of mints that were controlled by small political entities with often interlocking spheres of influence principalities, cities and church bodies. Coins did not carry value marks, allowing for market determined exchange rates. Therefore, imperfect coins could be used at their true metal weight, and silver and gold coins circulated side by side at variable exchange rates that reflected the market determined silver-gold ratio. Yet, although the unit of account was separate from the medium of exchange, pound money of account was not abstract. Instead, the official mint weight of an index coin, either through convention or some official decree, determined the purchasing power of each pound money of account.

Weber (1996) provides an econometric analysis of the monetary system of Basle during the late Middle Ages. Basle was a medium-sized city along the trade route from northern Italy across the Swiss Alps to Flanders and the Baltic, connecting the most prosperous regions of medieval Europe. The city was a significant commercial and political center within the loosely structured Holy Roman Empire (despite its name essentially Germany). A Church Council sat in Basle from 1431-37/48, which was attended by the Emperor in 1433-34. Coinage consisted of local silver pennies and foreign coins that had

${ }^{19}$ Van Werveke (1934) and de Roover (1948, pp. 220/221) questioned Einaudi's concept of imaginary money. Cipolla (1956, chs 4 and 5) discussed 'ghost moneys' in southern Europe. Lane and Mueller (1985, ch. 20) review the positions of economic historians on medieval pound moneys of account. White (1984) and Spufford (1988, Appendix II) reject the notion of abstract money. 
been acquired through trade. Popular gold coins included florins and ducats from Italy, and German rhinegulden. Commodity prices were quoted in local pound money of account and payments were made in an assortment of coins whose exchange rates were also expressed in pound. The econometric analysis of exchange rates by Weber (1996) shows that the behavior of the pound price of gold, the pound price of silver, and the silver-gold ratio cannot be reconciled with the notion that nominal values were autonomous. Instead, Basle's monetary system was based on the local silver penny, supplemented by foreign gold coins whose value in terms of $£ / s / d$ was determined by the official mint weight of the penny.

A metallic monetary standard does not provide a safeguard against inflation because the monetary authority can debase the index coin by reducing its weight and fineness. Spufford (1988) graphed the price of gold in terms of local pound moneys of account in a dozen medieval cities and countries, and Redish (2000) provides new time series for France and England. Particular violent inflations, in some cases repeatedly, occurred in Bohemia, France, Flanders, Austria, Castille and Cologne, whereas the pound units of the Italian city states, Aragon and England remained quite stable. The motives of deliberate inflation included seigniorage during fiscal emergencies and the redistribution of wealth between social groups. ${ }^{20}$ Since the nobility's income from feudal privileges was denominated in pound money of account, inflation shifted wealth away from the nobility to the ascendant mercantile class during the late Middle Ages. These inflationary episodes confirm that the government was in control of the mint weight of some index coin, manipulating it to its own advantage.

Debasements of the index coin, which produces inflation, must be distinguished from debasements of non-index coinage, which affects only exchange rates of coins. Medieval monetary authorities often interfered with currency markets, leading to Gresham type effects. Exchange rates between coins were fixed through official tariffs and not through explicit value marks. But this practice should not be overemphasized as enforcement of exchange rates was haphazard and eventually all coins traded at their true metal value. The monetary authorities imposed a seigniorage tax by issuing unmarked silver coins at overvalued rates, which were enforced in selective transactions. Not surprisingly, overvalued coins attracted

${ }^{20}$ Bordo (1986), Sussman (1993), Gandal and Sussman (1997), and Selgin and White (1999) stress the role of seigniorage in medieval public finance. Rolnick, Velde and Weber (1996) 
profiteers who tried to appropriate some of the government's profit by clipping coins. Governments fought off this unwanted competition with severe punishments, without much success. As a consequence, the quality of medieval silver coins was extremely poor, wear and tear and maltreatment often reduced their weight by one third or more. The quality of gold coins was better than that of silver coins because high-value gold coins were used at their metal weight in international transactions.

\section{Coinage on the Eve of the Industrial Revolution}

During the Middle Ages, most coins were manufactured by the method of striking, in which a blank piece of metal was placed between two dies and the upper die was struck with a hammer. Blanks were cut from cast metal rods that were hammered until they had the required thickness. ${ }^{21}$ The basic process of coinage, producing blanks and striking coins, did not change until the introduction of the rolling mill and screw press in the fifteenth and sixteenth centuries. Redish (2000) observes that the advantage of these new minting technologies was an improved quality of coins, whereas they did not reduce minting cost. Despite the introduction of the rolling mill and screw press, the quality of circulating coins remained poor because coins deteriorated once they were put into circulation, and replacing them was too costly before the mechanization of the process of coinage. The deterioration of coins occurred through wear and tear and, in the presence of unrealistic official tariffs, deliberate tampering. After the Revolution of 1688, the English government adopted wide ranging fiscal and monetary reforms, which also involved a recoinage of silver coins in 1695 . Since gold coins were officially overvalued, a de facto gold standard emerged, in which silver coins were used as means of payment only if they were worn or abused. Complaints about the low quality of British silver coins were frequent in the eighteenth century. Lord Liverpool (1805) reckoned that the average shilling had lost perhaps one sixth of its full weight and the average sixpence one quarter by $1760 .^{22}$

question the effectiveness of debasements, and Redish (2000) downplays the seigniorage motive for inflation.

${ }^{21}$ Some base metal coins whose exact metal weight was unimportant were directly cast. In Roman times, the blanks were cast and their weight was adjusted. See Cooper (1988) for technical information on the process of coinage.

${ }^{22}$ Craig (1953) includes sources on the wear of English coins back to the thirteenth century. 
The following anonymous account tells of fraudulent practices that were widespread in Great Britain during the eighteenth century, "my grandfather was a shorter ... by which is meant a gentleman who shortens or reduces the current coin of these realms, for which practice he was scragg'd, that is, hung by the scrag of the neck ... (he) shortened the coin of this country by three processes. By aquafortis, by clipping, and by filing. Filing and clipping he employed in reducing all kinds of coin, whether gold or silver; but aquafortis he used merely in reducing gold coin ... By laying a guinea in aquafortis for twelve hours he could filch from it to the value of ninepence ... the aquafortis eating the gold away and leaving it like a sediment in the vessel ... From a five-shilling piece ... he would file or clip to the value of fivepence, and from lesser coin in proportion" (Cooper 1988, pp. 42 and 125). But even in the absence of unrealistic exchange rates and abuse, it was too costly to replace worn pieces as long as the process of coinage remained a laborious process with few economies of scale.

A coin has three surfaces that may all carry designs - the top, the bottom and the narrow rim around the edge. The traditional method of coinage, striking, stamped an imprint on the top and bottom. In the eighteenth century, it became practical to protect coins against filing and clipping by putting designs on the rim. More importantly, the invention of industrial coining presses produced a quality improvement in coin circulation between 1780 and 1820. Matthew Boulton, who collaborated with James Watt, constructed a steam driven coining press in England in the 1780s. Paul Gengembre and Jean-Pierre Droz, both of the Paris Mint, designed mechanisms that automatically fed blanks and extracted coins. In 1817, Diedrich Uhlhorn, who had worked as engineer at the Dusseldorf Mint, patented the knuckle press, which had many applications in the metal-working industry besides coinage. The mechanization of mints improved the quality of coins for two reasons: it increased the standardization of coins and, by reducing minting cost, it made it economically feasible to replace worn pieces.

\section{$\underline{\text { 5. Nineteenth Century Bimetallism }}$}

Before the Industrial Revolution, the unit of account was separate from the medium of exchange because the quality of coins was poor. All coins, including the index coin, circulated at market determined exchange rates that were expressed in terms of the official mint weight of the index coin. The index coin stayed on an equal footing with other coins as 
medium of exchange until the quality improvement in coinage during the Industrial Revolution. Afterwards, the index coin and its multiples and fractions all circulated by tale. The unit of account function and medium of exchange function of the index coin fused, giving it a decisive advantage as medium of exchange. If the monetary unit was defined in terms of silver, all silver coins circulated by tale, while gold coins continued to trade at exchange rates that depended on the market determined silver-gold ratio. In this situation, silver coins gained an advantage as medium of exchange because their ability to pass by tale reduced transaction costs. Vice versa, gold coins became the primary medium of exchange if the monetary unit was defined in terms of gold. The quality improvement in coinage accounted for the transformation of the monetary system from pre-industrial bimetallism to de facto monometallism at the turn of the eighteenth to the nineteenth centuries. Value marks played no role in the demise of pre-industrial bimetallism, although they accounted for the difficulties of nineteenth century bimetallism. The unit of account function and medium of exchange function of the index coin would have fused with or without the use of value marks. Actually, the introduction of value marks is just another indication of the quality improvement in coins because it seems natural to put value marks on high quality coins that circulate by tale. Thus, technological advance in the process of coinage explains both the emergence of de facto monometallism and the adoption of value marks.

The demise of bimetallism during the Industrial Revolution may be thought of as having occurred in two steps. First, the quality improvement in coinage gave rise to de facto monometallism by fusing the unit of account function of the index coin with the medium of exchange function. The ability to circulate by tale gave the index coin and its multiples and fractions a decisive advantage as medium of exchange. Second, the use of value marks representing a single monetary unit engendered fixed exchange rates between silver and gold coins. This created an alternating bimetallic standard in which, depending on market conditions, the make of the currency shifted between silver and gold. The first step, the emergence of de facto monometallism, was an unavoidable consequence of technological advance in the process of coinage during the Industrial Revolution. The second step, the formation of an alternating bimetallic standard, was not strictly necessary because there was no need to put unitary value marks representing a single monetary unit on both silver and gold coins. However, transaction costs precluded a system of parallel currencies in which silver and gold coinage - each carrying its own set of value marks representing different 
monetary units - would have circulated at market determined exchange rates relative to each other. $^{23}$

\section{$\underline{\text { 6. Conclusion }}$}

The main objective of this study is to show that the concept of index coin is fruitful in the analysis of the vast amount of source material that has been collected by monetary historians and numismatists. The notion of index coin is a theoretical construct whose merit can be established only by applying it in historical monetary research. The index coin hypothesis is attractive because it employs economic theory: standard price theory explains the exchange value of a unit of monetary metal, and the official mint weight of the index coin anchors the purchasing power of the unit of account. There exists no competing hypothesis in the literature on monetary history and numismatics that is equally successful in explaining the operation of a metallic monetary standard with heterogeneous coinage. The hypothesis of an abstract unit of account caused hopeless confusion among monetary historians and numismatists. Most monetary historians have discarded the notion of an abstract unit of account because, after decades of research, it has turned out to be a hindrance to the understanding of metallic monetary standards, instead of a help.

Monetary economists have neglected the history of bimetallism. This is hard to understand because bimetallism completely dominated monetary history, accounting for about nine-tenths of it. The history of money is the history of bimetallism. The lack of a satisfactory analysis of pre-industrial bimetallism exposes a gap in monetary economics that requires an explanation. Three tacit assumptions render modern monetary economics unsuitable for the analysis of early monetary systems. Monetary economists take it for granted that money is both unit of account and medium of exchange; currency is viewed as a homogenous aggregate whose components exchange at par; and the supply conditions of money are stripped down to the bare minimum, often involving only paper money that is supplied at no cost by the government. All three assumptions are appropriate abstractions in

${ }^{23}$ Transaction costs also precluded a bimetallic system in which, say, value marks were put only on silver coins, allowing them to pass at par, while unmarked gold coins continued to circulate at market determined exchange rates. A bimetallic system in which one type of coin did not carry value marks was proposed during the public debate preceding the enactment of the subsidiary coinage bill in the United States in 1853 (See Martin (1973), footnote 69). 
the modern world, facilitating the analysis of national monetary systems that are run by central banks. However, these assumptions have been detrimental to the understanding of bimetallism and its transformation during the Industrial Revolution. Before the Industrial Revolution the unit of account was separate from the medium of exchange, local currency consisted of a multitude of coins whose exchange rates were market determined, and currency was supplied competitively by a large number of mints at nontrivial costs.

Bimetallism had become a dysfunctional relic by the early nineteenth century, although it lingered on for another seventy years. Sporadic changes between gold and silver coinage accounted for monetary instability. A switch from gold to silver increased the demand for bank notes and sight deposits relative to coins because heavy silver coins were inconvenient in commercial transactions. This produced an influx of funds into the banks that led to an expansion of credit. A change from silver to gold had the opposite effect, reducing bank reserves and credit. Despite the shortcomings of nineteenth century bimetallism, silver mining interests strongly lobbied for the maintenance of bimetallism, in particular in the United States. ${ }^{24}$ But genuine bimetallism remained elusive because it was no longer supported by the fundamental technological and institutional conditions governing the process of coinage. In 1934, the United States made an ill-advised, last attempt to restore bimetallism, preparing for silver coinage by buying huge quantities of silver. As a consequence, the world price of silver increased, inducing an overvaluation of the silver currencies of China and India. This contributed to the ruin of the Chinese monetary system at a critical juncture of Chinese history. ${ }^{25}$

This study sheds light on a recent strand of monetary research that deals with laissezfaire monetary systems. Hayek (1976/78) proposed that currencies should be issued competitively in order to achieve price stability. Accordingly, it has been argued that Europe

White (1984) suggested that transaction costs lead to a single unit of account in a competitive monetary system.

${ }^{24}$ Friedman and Schwartz (1963, pp. 113-119) discuss the 'Politics of Silver' in the United States.

${ }^{25}$ Cassel (1936, ch. 7) and Friedman (1992, ch. 7) criticize American silver policy during the Great Depression in the 1930s. 
should adopt a system of parallel currencies, instead of a single monetary unit. ${ }^{26}$ The preceding analysis shows that the concept of parallel currencies is ahistoric and implausible. Before the Industrial Revolution, there existed a strong tendency toward a single unit of account in the form of an index coin within an economic area, although mixed media of exchange were common. ${ }^{27}$ The tendency toward a uniform unit of account within a single economic area is a key feature of monetary history. Yet, the emergence of a single unit of account defeats the purpose of competitive currency schemes. The adoption of a single unit of account in Europe has been successful because it fits a well established historical pattern.

${ }^{26}$ Selgin and White (1994) review the literature on laissez-faire monetary systems. Salin (1984), Vaubel (1990) and De Grauwe (1997, pp. 165-170) deal with the parallel currency approach to European monetary unification.

27 In China the tael system of account survived until the twentieth century. Like preindustrial European pound units, tael units represented fixed amounts of silver. There were many local tael units, but usually a single unit of account prevailed in a city. King (1965) deals with the tael system during the second half of the nineteenth century. Glahn (1996) discusses Chinese money and monetary policy from 1000 to 1700. 


\section{$\underline{\text { References }}$}

Barro, R.J. "Money and the Price Level under the Gold Standard." Economic Journal 89 (March 1979): 13-33.

Bordo, M.D. "Money, Deflation and Seigniorage in the $15^{\text {th }}$ Century." Journal of Monetary Economics 18 (November 1986): 337-46.

Burnett, A. Coinage in the Roman World. London: Seaby, 1987.

Burns, A.R. Money and Monetary Policy in Early Times. London: Kegan Paul, Trench, Trubner (New York: Alfred A. Knopf), 1927.

Carradice, I. and Price, M.. Coinage in the Greek World. London: Seaby, 1988.

Cassel, G.. The Downfall of the Gold Standard. Oxford: Clarendon Press, 1936.

Cipolla, C.M. Money, Prices and Civilization in the Mediterranean World. Princeton: Princeton University Press, 1956.

Collis, J. The European Iron Age. London: B.T. Batsford, 1984.

Cooper, D.R. The Art and Craft of Coinmaking. A History of Minting Technology. London: Spink \& Son, 1988.

Craig, J. The Mint. A History of the London Mint from AD 287 to 1948. Cambridge: At the University Press, 1953.

Crawford, M.H. Roman Republican Coinage. Vol. I and II. Cambridge: Cambridge University Press, 1974.

Crawford, M.H. Coinage and Money Under the Roman Republic. London: Methuen \& Co., 1985.

Dowd, K. "The Analytics of Bimetallism." The Manchester School of Economic \& Social Studies 64 (September 1996): 281-97.

Eichengreen, B.J. Globalizing Capital. A History of the International Monetary System. Princeton: Princeton University Press, 1996.

Einaudi, L. "The Theory of Imaginary Money from Charlemagne to the French Revolution." In Lane F.C. and Riemersma J.C. (eds). Enterprise and Secular Change. London: Allen and Unwin, 1953 ("Teoria della moneta immaginaria net tempo da Carlomagno all rivoluzione francese." Rivista di storia economica (1936).) 
Einaudi, L. "The Medieval Practice of Managed Currencies." In Gayer, A.D.. The Lessons of Monetary Experience. Essays in Honour of Irving Fisher. London: Allen \& Unwin, 1937.

Flandreau, M. "The French Crime of 1873: An Essay on the Emergence of the International Gold Standard, 1870-1880." The Journal of Economic History 56 (December 1996): 862-97.

Flandreau, M. The Glitter of Gold. Oxford: Oxford University Press, 2004.

Friedman, M. "Commodity-Reserve Currency." Journal of Political Economy 59 (June 1951): 203-32.

Friedman, M. "The Crime of 1873." Journal of Political Economy 98 (December 1990): 1159-94. (a)

Friedman, M. "Bimetallism Revisited.” Journal of Economic Perspectives 4 (Fall 1990): 85104. (b)

Friedman, M. "FDR, Silver, and China." Journal of Political Economy 100 (February 1992): 62-83.

Friedman, M. and Schwartz, A.J. A Monetary History of the United States, 1867-1960. Princeton: Princeton University Press.

Gallarotti, G.M. "The Scramble for Gold: Monetary Regime Transformation in the 1870s." In Bordo, Michael D. and Capie, Forrest (eds.). Monetary Regimes in Transition. Cambridge: Cambridge University Press, 1994.

Gandal, N. and Sussman, N. "Asymmetric Information and Commodity Money: Tickling the Tolerance in Medieval France." Journal of Money, Credit and Banking 29 (November 1997): 440-57.

von Glahn, R. Fountain of Fortune: Money and Monetary Policy in China. 1000-1700. Berkeley: University of California Press, 1996.

de Grauwe, P. The Economics of Monetary Integration. $3^{\text {rd }}$ ed., Oxford: Oxford University Press, 1997.

Harl, K.W. Coinage in the Roman Economy, 300 B.C. to A.D. 700. Baltimore: The Johns Hopkins University Press, 1996.

Hayek, F.A. Denationalisation of Money. London: the Institute of Economic Affairs, $1976 / 78$ 
Heichelheim, F. Wirtschaftliche Schwankungen der Zeit von Alexander bis Augustus. Jena: Gustav Fischer, 1930.

King, F.H. Money and Monetary Policy in China, 1845-1895. Cambridge, MA: Harvard University Press, 1965.

Lane, F.C. and Mueller, Reinhold C. Money and Banking in Medieval and Renaissance Venice. Coins and Moneys of Account. Vol. I. Baltimore: John Hopkins University Press, 1985.

Liverpool, C.J. A Treatise on the Coin of the Realm. Oxford: At the University Press, 1805.

Marshall, A. "Remedies for Fluctuations of General Prices." Contemporary Review 51 (March 1887). (Reprinted in Pigou, A.C. (ed.). Memorials of Alfred Marshall. London: Macmillan, 1925.)

Martin, D.A. "1853: The End of Bimetallism in the United States." The Journal of Economic History 33 (December 1973): 825-44.

McCallum, B.T. "The Gold Standard: A Commodity Money System." In Monetary Economics. New York: Macmillan, 1989, (ch. 7).

Melville-Jones, J.R. A Dictionary of Ancient Greek Coins. London: B.A. Seaby, 1986

Melville-Jones, J.R. A Dictionary of Ancient Roman Coins. London: B.A. Seaby, 1990.

Melville-Jones, J.R. Testimonia Numaria. Vol I. London: Spink, 1993.

Mommsen, T. Geschichte des Römischen Münzwesens. Berlin: Weidman, 1860. (Reprinted by Akademische Druck u. Verlagsanstalt, Graz, 1956)

Nash, D.. Coinage in the Celtic World. London: Seaby, 1987.

Niehans, J. "Commodity Money." In The Theory of Money. Baltimore: Johns Hopkins University Press, 1978.

Oppers, S.E. "Was the Worldwide Shift to Gold Inevitable? An Analysis of the End of Bimetallism." Journal of Monetary Economics 37 (February 1996): 143-62.

Redish, A. "The Evolution of the Gold Standard in England." Journal of Economic History 50 (December 1990): 789-805.

Redish, A. "The Persistence of Bimetallism in Nineteenth-Century France." The Economic History Review 48 (November 1995): 717-36.

Redish, A. Bimetallism: An Economic and Historical Analysis. Cambridge: Cambridge University Press, 2000. 
Rolnick, A.J., Velde, F.R. and Weber, W.E. "The Debasement Puzzle: An Essay on Medieval Monetary History." The Journal of Economic History 56 (December 1996): 789-808.

Rolnick, A.J. and Weber, W.E. "Gresham's Law or Gresham's Fallacy?" Journal of Political Economy 94 (February 1986): 185-200.

de Roover, R. Money, Banking, and Credit in Medieval Bruges: Italian Merchant-Bankers, Lombards, and Money Changers. Cambridge, MA: Medieval Academy of America, 1948.

Salin, P. (ed.) Currency Competition and Monetary Union. The Hague: Martinus Nijhoff, 1984.

Sargent, T.J. and Smith, B.D. "Coinage, Debasements, and Gresham's Laws." Economic Theory 10 (August 1997): 197-226.

Sargent, T.J. and Velde, F.R. "The Big Problem of Small Change." Princeton: Princeton University Press, 2002.

Selgin, G. "Steam, Hot Air, and Small Change: Matthew Boulton and the Reform of Britain's Coinage.” Economic History Review LVI (August 2003): 478-509.

Selgin G. and White, L.H. "How Would the Invisible Hand Handle Money?" Journal of Economic Literature 32 (December 1994): 1718-49.

Selgin G. and White, L.H. "A Fiscal Theory of Government's Role in Money." Economic Inquiry 37 (January 1999): 154-165.

Spufford, P. Money and Its Use in Medieval Europe. Cambridge: Cambridge University Press, 1988.

Sussman, N. "Debasements, Royal Revenues, and Inflation in France During the Hundred Years' War, 1415-1422." The Journal of Economic History 53 (March 1993): 44-70.

Vaubel, R. "Currency Competition and European Monetary Integration." Economic Journal 100 (1990): 936-46.

Weber, E.J. "'Imaginary' or 'Real' Moneys of Account in Medieval Europe? An Econometric Analysis of the Basle Pound, 1365-1429." Explorations in Economic History 33 (1996): 479-95.

van Werveke, H. "Monnaie de compte et monnaie reelle." Revue belge de philologie et d'historie 13 (1934): 123-52 (Reprinted in Miscellanea Mediavalia, Ghent, 1968). 
White, L.H. "Competitive Payments Systems and the Unit of Account." American Economic Review 74 (September 1984): 699-712. 